\title{
Influence of soil texture and bed preparation on growth performance in Plectranthus vettiveroides
}

\author{
P.M. Safeer ${ }^{1}$, S. Sreekumar ${ }^{2}$, P. N. Krishnan ${ }^{3}$, C. K. Biju ${ }^{4}$ and G. Seeja ${ }^{5}$ \\ ${ }_{1,2,3,4}$ Saraswathy Thangavelu Centre, Jawaharlal Nehru Tropical Botanic Garden and Research Institute, \\ Thiruvananthapuram - 695586, Kerala \\ ${ }^{5}$ Department of Plant Breeding \& Genetics, College of Agriculture, Vellayani, Thiruvananthapuram, \\ ${ }^{2}$ Corresponding author
}

\begin{abstract}
As part of development of agrotechnology package of practices for large scale cultivation of Plectranthus vettiveroides experiments were conducted to study the effect of soil texture using different ratios of sand and loam soil. Experiments were also conducted to study the influence of land preparation methods for optimum growth and yield attributes. The results revealed that in pure sandy soil raised bed of $60 \mathrm{~cm}$ height with a layer of coconut husks at entire edges of top boundary can be recommended for the optimum growth and yield attributes in $\underline{P}$. vettiveroides.
\end{abstract}

Key words: Growth, Plectranthus vettiveroides, Sand, Soil, Yield, Raised bed

\section{Introduction}

Plectranthus vettiveroides (K.C. Jacob) N. P. Singh \& B. D. Sharma (Syn. Coleus vettiveroides) locally known as 'iruveli' in Malayalam and 'vettiver' or 'kuruver' in Tamil belongs to the family Lamiaceae is a medicinal succulent herb with strongly aromatic fibrous roots. It has been used as antibacterial, deodorant, cooling agent [1] and also used against eye burning, head ache and fever [2]. The essential oil obtained from the roots has antimicrobial property and has been used by physicians especially in the western countries as a sanitation agent and hand wash [3]. In Tamil Nadu the root has been used for worshipping the deity and also used for making household products such as bathing soap, agarbatti, hair oil etc [4]. About 40 herbal drugs are currently available in the global/local market containing $P$. vettiveroides as single or as an ingredient $[1,5]$. The plant is endemic to South India and now extinct in the wild. Currently, the plant has been cultivated by few farmers of the village Kollidam, Chidambaram, Cuddalore district, Tamil Nadu, where its cultivation is associated with some religious belief and as part of that they are forbidden to give out the planting material. At present, demand for the root is rocketing but its commercial scale cultivation is not being practiced and popularised mainly due to the lack of standardised agrotechnological package of practices. In the light of these, the National Medicinal Plants Board (NMPB), Government of India has recognised the plant as a top priority one for conservation and sustainable utilisation through large scale cultivation.

As part of standardising agrotechnology package of practices, the present study aimed to find out best soil type and mode of soil bed preparation for optimum growth and root biomass yield. Soil is a heterogeneous material which may be considered as consisting of three major components; a solid phase, a liquid phase and a gaseous phase [6]. Soil types influences the growth of plants directly or indirectly by interacting with a large number of factors and have been studied in different crops like sweet pepper [7]. The water infiltration rate has direct influence on the morphological characters [8]. Optimum moisture condition for any crop may vary depending on many factors such as soil type, climate conditions, growth rate, habit etc. The favourable soil moisture condition should be maintained throughout the growth period of plants due to the relationship between evapotranspiration and biomass production [9]. Proper land preparation is required for vigorous growth of plants. Soil management practices like tillage was useful for improving soil properties and enhanced crop performance $[10,11,12]$.

\section{Material And Methods}

Field experiments were conducted at Jawaharlal Nehru Tropical Botanic Garden and Research Institute (JNTBGRI), Puthenthope campus, Thiruvananthapuram situated at $8^{\circ} 34^{\prime} 51$ "N latitude and $76^{\circ} 50^{\prime} 3$ "E longitude during 2010-2012. To determine the best soil texture and type sandy and loamy soil in five different combinations (100:0, 75:25, 50:50, 25:75, 0:100) were filled in earthen pots of nine inch height and 11 inch diameter and $10-15 \mathrm{~cm}$ long shoot tip cuttings were planted. To determine the influence of land preparation methods, raised soil bed heights $(15 \mathrm{~cm}, 30 \mathrm{~cm}, 45 \mathrm{~cm}, 60 \mathrm{~cm}, 75 \mathrm{~cm})$ and boundaries using different materials such as thatched coconut leaves, ferro-cement hollow bricks and coconut husks around top edges were tested for growth and yield. The physical and chemical parameters of the soil were determined just before planting. The 
plants were kept under light intensity of 6550 to 12000 lux and irrigated twice daily and harvested after 70 days of cultivation.

Experiments were laid out in Randomized Block Design (RBD) replicated thrice. Observations on survival percentage, plant height $(\mathrm{cm})$, leaves/plant, leaf area/plant $\left(\mathrm{m}^{2}\right)$, branches/plant, shoot biomass/plant $(\mathrm{g})$, primary roots/plant, root length/plant $(\mathrm{cm})$ and root biomass/plant $(\mathrm{g})$ were recorded after 70 days of growth. To determine the essential oil yield the harvested fresh roots were hydro-distilled in Clevenger apparatus for 4 hours. All the data were statistically analyzed by analysis of variance (ANOVA) and critical difference (CD) at $5 \%$ level for comparing the treatment means.

\section{Results And Discussion}

The highest soil $\mathrm{pH}(6.25)$ was recorded in sandy soil (100:0) and lowest $\mathrm{pH}(4.25)$ in loamy sand (0:100). The percentage of sand, clay and silt particles present in individual and different combinations of sand and clay soils were depicted in (Table 1). According to Ritu et al. (2010) the acidity of soil increases in accordance with increasing clay content. The chemical properties of different soil ratios (Table 2) showed that Nitrogen was recorded maximum $(0.6 \%)$ in loamy sand and minimum $(0.24 \%)$ in sandy soil. Phosphorous was maximum $(19 \mathrm{ppm})$ in sandy soil and minimum in loamy sand $(5.25 \mathrm{ppm})$. Potassium was maximum $(9.25 \mathrm{ppm})$ in sandy clay loam and minimum in sandy soil $(4.25 \mathrm{ppm})$. Micronutrients of the soil were also tested and depicted in Table 2. Of the different soil ratios tested, maximum survival rate (100\%) was recorded in sandy soil and least survival rate (53\%) noticed in sandy clay loam (Table 3). Significant differences were exhibited with different soil types on growth attributes (Table 4 and Fig 1). All the parameters such as plant height $(43.81 \mathrm{~cm})$, number of branches (22.13), number of leaves $(40.13)$, leaf area $\left(8.43 \mathrm{~m}^{2}\right)$, fresh shoot weight $(101.75 \mathrm{~g})$, root length $(48.00 \mathrm{~cm})$, number of primary roots $(20.25)$ and root biomass $(33.80 \mathrm{~g})$ per plant were recorded maximum in sandy soil and significantly superior over other soil types. Although nitrogen content was low in sandy soil the growth and yield was significantly higher. It indicates that sandy soil texture play crucial role on the growth and yield of Plectranthus vettiveroides. Better growth performance and biomass yield in sandy soil might be due to larger sand particles, separated by greater space which holds more oxygen but less water (due to rapid drainage) providing better aeration in contrast to the smaller clay particles which are more compact and hold more water and less oxygen. The longest root length in sand may be attributed by low nutrient and water supply $[14,15,16]$. Percentage of oil content was also high $(0.32 \%)$ in sandy soil compared to other soil types. Excess water can cause anaerobic condition that might be one of the causal factors for the reduced growth in other soil types $[17,18]$. Clay and silt particles may have negative effects on plants by accumulation of excess water that inhibit growth rate of plant [19].

Influence of different soil raised bed heights was tested and the results revealed that maximum root production was recorded in $60 \mathrm{~cm}$ bed height (Table 5). The analysis of data revealed that up to $60 \mathrm{~cm}$ bed height root biomass was increased and then biomass yield declined. The observations indicated that raised soil bed from the surface of the soil favoured increased root length. There was no significant difference in primary roots indicate that maximum root growth was attained at a depth of $60 \mathrm{~cm}$ and further increase in bed height could only increase the length of the root and that could not contribute much to root biomass. The influence of root growth and soil bed height was also studied in green crops [20]. Highest mean plant height $(40.83 \mathrm{~cm})$, number of leaves/plant (84) and number of branches/ plant (10.33) were recorded in bed height of 75 $\mathrm{cm}$. Maximum leaf area/plant $\left(17.64 \mathrm{~m}^{2}\right)$ was recorded in $75 \mathrm{~cm}$ height bed may be due to more number of leaves per plant when compared to other bed heights. Shoot weight/plant $(194.17 \mathrm{~g})$ was also maximum at $75 \mathrm{~cm}$ bed height when compared to other treatments was due to increase in above ground characters. Maximum root length $(69.33 \mathrm{~cm})$ in $75 \mathrm{~cm}$ bed height may be due to increased root penetration through the soil before hitting the hard soil. Maximum number of primary roots $(18.67)$ in $60 \mathrm{~cm}$ bed height may be due to the reason that it provides more favourable root-zone conditions for root growth. It provides optimum condition for water infiltration and proper aeration which favoured root growth horizontally hence ridge height of $60 \mathrm{~cm}$ determined the maximum root yield per plant $(37.95 \mathrm{~g})$. This could be due to the fact that at this ridge height all the necessary conditions for an ideal root formation were satisfied, both the number of primary roots and length were maximum and so resulted highest yield. This was in corroborated with the earlier reports in sweet potato that neither too high nor too low ridge heights results to high tuber yield [21,22]. Raised beds improve drainage and aeration of the root zone following irrigation, leading to good root development. More favourable root-zone conditions exist for plant growth since there is a greater depth of surface soil, so rapid reaeration of the rootzone occurs following irrigation or rainfall. The raised bed land preparation was therefore recommended for optimum growth and yield in Plectranthus vettiveroides, as reported in pepper [23], and bed height of $60 \mathrm{~cm}$ was optimum for maximum growth and yield.

Raised bed boundaries covered with coconut husks at the top recorded maximum mean shoot $(79.58 \mathrm{~g})$ and root $(56.25 \mathrm{~g})$ biomass per plant. The former may be due to maximum plant height $(42.42 \mathrm{~cm})$ and large number of branches (10.1), and latter may be due to higher number of primary roots (21.5) and its' spreading 
(Table 5). In fact, coconut husks layered at the top boundary of the raised soil bed provided ambient moisture condition to the soil, which induced better plant growth. Soil bed made using thatched coconut leaves produced large number of leaves (50.5), hence recorded maximum leaf area $\left(10.52 \mathrm{~m}^{2}\right)$, and also recorded maximum root length $(71.42 \mathrm{~cm})$ which was highly significant to other treatments. The growth and yield of crops are highly influenced by available soil moisture [24].

\section{FIGURE}

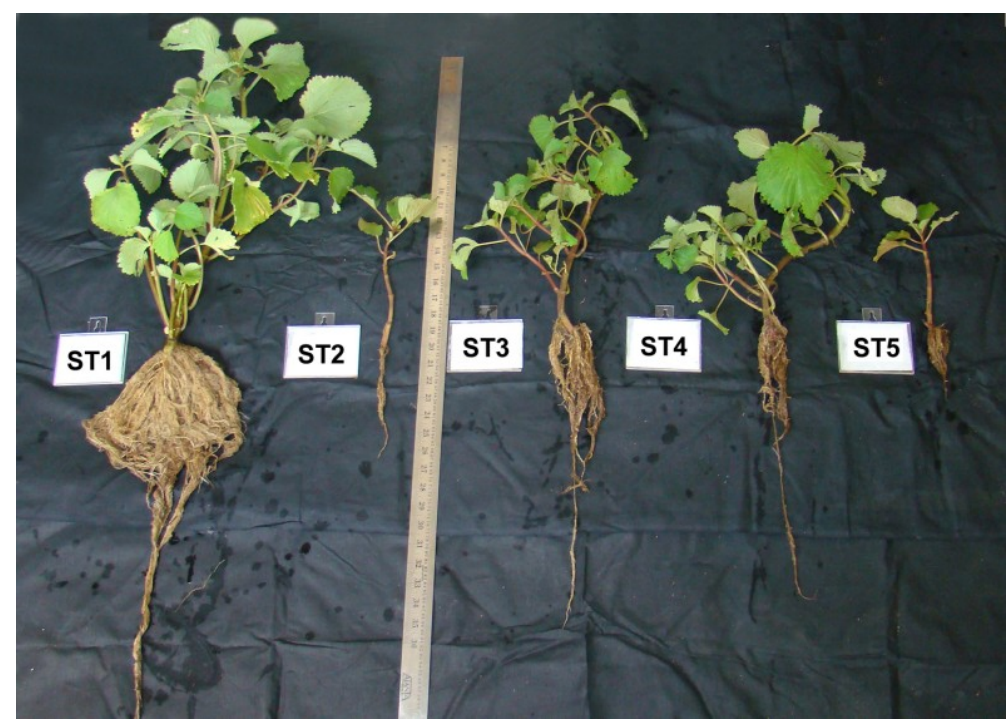

Fig 1: Influence of soil types on growth and yield in Plectranthus vettiveroides after 70 days of growth period. ST1-sand:loam (100:0), ST2-sand:loam (25:75), ST3-sand:loam (75:25), ST4-sand:loam (50:50), ST5sand:loam $(0: 100)$.

\section{TABLES}

Table 1. Soil $\mathrm{pH}$ and physical properties of different soil combinations.

\begin{tabular}{|l|c|c|c|c|c|}
\hline \multirow{2}{*}{ Parameters } & \multicolumn{5}{|c|}{ Soil ratio (sand:loam) } \\
\cline { 2 - 6 } & $100: 0$ & $75: 25$ & $50: 50$ & $25: 75$ & 5 \\
\hline $\mathrm{pH}$ & 6.25 & 5.1 & 5.2 & 84.15 & 4.85 \\
\hline Sand (\%) & 97.94 & 86.44 & 85.67 & 2.38 & 72.82 \\
\hline Silt (\%) & 0.81 & 1.06 & 0.85 & 13.48 & 1.18 \\
\hline Clay (\%) & 1.25 & 12.5 & 13.49 & loamy sand & sandy clay loam \\
\hline Texture & sandy soil & loamy sand & loamy sand & & \\
\hline
\end{tabular}

Table 2. Chemical properties of different soil combinations

\begin{tabular}{|c|c|c|c|c|c|}
\hline \multirow[b]{2}{*}{ Chemical Parameters } & \multicolumn{5}{|c|}{ Soil ratio (sand:loam) } \\
\hline & $100: 0$ & $75: 25$ & $50: 50$ & $25: 75$ & $0: 100$ \\
\hline $\mathrm{EC}$ & 0.035 & 0.035 & 0.045 & 0.04 & 0.035 \\
\hline $\mathrm{N}$ (as organic carbon \%) & 0.24 & 0.3 & 0.34 & 0.6 & 0.28 \\
\hline $\mathrm{P}$ & 19 & 16.5 & 10.75 & 5.25 & 12 \\
\hline $\mathrm{K}$ & 4.25 & 8.75 & 6.75 & 8.75 & 9.25 \\
\hline $\mathrm{Ca}$ & 34.25 & 54.75 & 39.5 & 67.75 & 64.5 \\
\hline $\mathrm{Mg}$ & 37.5 & 45 & 30 & 55 & 57.5 \\
\hline $\mathrm{S}$ & 3.75 & 9.375 & 26.25 & 47.5 & 95.625 \\
\hline $\mathrm{Fe}$ & 7.6 & 9.1 & 7.76 & 8.4 & 11.64 \\
\hline $\mathrm{Mn}$ & 0.62 & 1.03 & 1.45 & 1.87 & 4.88 \\
\hline $\mathrm{Cu}$ & 0.16 & 0.31 & 0.22 & 0.26 & 0.34 \\
\hline $\mathrm{Zn}$ & 0.3 & 0.42 & 0.5 & 0.44 & 0.58 \\
\hline B & 1.35 & 1.45 & 1.25 & 1.15 & 2.45 \\
\hline
\end{tabular}


Table 3. Survival percentage of Plectranthus vettiveroides at different time intervals in different ratio of sand and loam soil

\begin{tabular}{|l|r|r|r|r|r|r|r|}
\hline \multirow{2}{*}{$\begin{array}{l}\text { Treatment } \\
\text { Sand : Loam }\end{array}$} & \multicolumn{7}{|c|}{ Survival \% at 10 days interval } \\
\cline { 2 - 8 } & 10 days & 20 days & 30 days & 40 days & 50 days & 60 days & 70 days \\
\hline $100: 0$ & 100 & 100 & 100 & 100 & 100 & 100 & 83 \\
\hline $75: 25$ & 100 & 92 & 92 & 92 & 92 & 62 & 67 \\
\hline $50: 50$ & 100 & 92 & 92 & 92 & 92 & 67 & 67 \\
\hline $25: 75$ & 100 & 92 & 92 & 92 & 82 & 53 \\
\hline $0: 100$ & 100 & 92 & & & 52 \\
\hline
\end{tabular}

Table 4. Growth and yield attributes of Plectranthus vettiveroides in different soil type.

\begin{tabular}{|c|c|c|c|c|c|c|c|}
\hline Sand : Loam ratio & $100: 0$ & $75: 25$ & $50: 50$ & $25: 75$ & $0: 100$ & $\mathrm{~S} . \mathrm{Em} \pm$ & C.D $(0.05)$ \\
\hline Plant height $(\mathrm{cm})$ & 43.81 & 37.00 & 32.19 & 23.40 & 19.80 & 1.06 & 3.86 \\
\hline Branches/ plant & 22.13 & 20.38 & 19.00 & 16.75 & 14.20 & 1.13 & 4.12 \\
\hline Leaves/plant & 40.13 & 23.63 & 17.25 & 9.25 & 7.40 & 3.56 & 12.92 \\
\hline Leaf area/ plant $\left(\mathrm{m}^{2}\right)$ & 8.43 & 4.96 & 3.62 & 1.94 & 1.55 & 0.7 & 2.5 \\
\hline Fresh shoot weight/plant (g) & 101.75 & 46.31 & 27.56 & 12.20 & 9.70 & 10.56 & 38.39 \\
\hline Number of primary roots/ plant & 20.25 & 11.75 & 11.38 & 9.63 & 9.40 & 1.8 & 6.55 \\
\hline Root length/plant (cm) & 48.00 & 32.63 & 26.31 & 11.80 & 11.50 & 2.63 & 9.54 \\
\hline Fresh root weight/plant $(\mathrm{g})$ & 33.80 & 10.00 & 5.75 & 1.31 & 1.02 & 5.19 & 18.86 \\
\hline Oil yield (\% fresh wt.) & 0.32 & 0.30 & 0.29 & 0.31 & 0.30 & 0.005 & $\mathrm{NS}$ \\
\hline
\end{tabular}

Table 5. Influence of soil bed height and materials used for bed boundary preparation on growth and yield in Plectranthus vettiveroides.

\begin{tabular}{|c|c|c|c|c|c|c|c|c|}
\hline Height of soil beds (cm) & $\begin{array}{l}\text { Plant } \\
\text { height } \\
(\mathrm{cm})\end{array}$ & $\begin{array}{l}\text { Leaves } \\
\text { /plant }\end{array}$ & $\begin{array}{l}\text { Leaf } \\
\text { area/ } \\
\text { plant } \\
\left(\mathrm{m}^{2}\right)\end{array}$ & $\begin{array}{l}\text { Number } \\
\text { of } \\
\text { branches } \\
\text { / plant }\end{array}$ & $\begin{array}{l}\text { Fresh } \\
\text { shoot } \\
\text { weight } \\
\text { (g/plant) }\end{array}$ & $\begin{array}{l}\text { Number of } \\
\text { primary } \\
\text { roots/ plant }\end{array}$ & $\begin{array}{l}\text { Root } \\
\text { length } \\
\text { /plant } \\
(\mathrm{cm}) \\
\end{array}$ & $\begin{array}{l}\text { Fresh } \\
\text { root } \\
\text { weight } \\
\text { (g/plant) }\end{array}$ \\
\hline $15 \mathrm{~cm}$ & 29.50 & 43.50 & 9.14 & 4.83 & 115.83 & 18.17 & 26.83 & 24.57 \\
\hline $30 \mathrm{~cm}$ & 40.63 & 78.38 & 16.46 & 8.63 & 187.00 & 18.13 & 41.16 & 32.29 \\
\hline $45 \mathrm{~cm}$ & 39.83 & 80.33 & 16.87 & 8.33 & 191.67 & 18.00 & 49.33 & 35.23 \\
\hline $60 \mathrm{~cm}$ & 40.67 & 82.83 & 17.40 & 10.17 & 193.67 & 18.67 & 58.50 & 37.95 \\
\hline $75 \mathrm{~cm}$ & 40.83 & 84.00 & 17.64 & 10.33 & 194.17 & 18.50 & 69.33 & 37.27 \\
\hline F Test & * & $*$ & * & $*$ & * & NS & * & * \\
\hline S.Em \pm & 2.2 & 7.64 & 1.60 & 0.99 & 15.21 & 0.13 & 7.3 & 2.43 \\
\hline C.D (0.05) & 3.52 & 7.94 & 1.67 & 2.07 & 12.56 & NS & 17.00 & 2.06 \\
\hline \multicolumn{9}{|l|}{$\begin{array}{l}\text { Material for soil bed boundary } \\
\text { preparation }\end{array}$} \\
\hline Thatched Coconut leaves & 32.13 & 50.50 & 10.52 & 9.6 & 72.58 & 19 & 71.42 & 44.25 \\
\hline Hollow bricks & 29.50 & 28.17 & 5.94 & 7 & 66.67 & 17 & 51.83 & 17.83 \\
\hline $\begin{array}{l}\text { Coconut husk layered at top } \\
\text { boundary }\end{array}$ & 42.42 & 38.67 & 8.12 & 10.1 & 79.58 & 21.5 & 45.58 & 56.25 \\
\hline Control & 35.58 & 29.83 & 6.25 & 10 & 60.08 & 19 & 44.58 & 36.75 \\
\hline F Test & $*$ & $*$ & $*$ & * & NS & * & * & $*$ \\
\hline S.Em \pm & 2.34 & 2.36 & 0.52 & 0.73 & 5.66 & 0.92 & 2.29 & 1.71 \\
\hline C.D (0.05) & 7.64 & 7.72 & 1.69 & 1.15 & & 1.15 & 7.47 & 5.58 \\
\hline
\end{tabular}

\section{Conclusion}

Based on the experimental results it is recommended to cultivate Plectranthus vettiveroides in raised sandy soil bed of $60 \mathrm{~cm}$ height and covered with a layer of coconut husks at top boundary of the bed.

\section{ACKNOWLEDGEMENTS}

The authors are highly thankful to National Medicinal Plants Board (NMPB), Government of India for financial support, Central Soil Analytical Laboratory, Soil Survey Organisation, Thiruvananthapuram, Government of Kerala for the analysis of soil samples and the Director, JNTBGRI for providing the facilities and encouragements. 


\section{References}

[1]. T.N. Shivananda, B. Mamatha and A.N. Ganeshamurthy, Problems and prospects in cultivation of Plectranthus vettiveroides (K.C. Jacob) N.P. Singh \& B.D. Sharma, Limitations in identification, nomenclature, distribution and cultivation-A case study, Biomed. 2 (2), 2007, 146-154.

[2]. P.K. Warrier, Indian Medicinal Plants: A Compendium of 500 species (Orient Longman, 1995).

[3]. Sunanda Mondal and S.A. Kolhapure, Evaluation of antimicrobial efficacy and safety of pure hands herbal hand sanitizer in hand hygiene and on inanimate objects, The Antiseptic, 101(2), 2004, 55-57.

[4]. K.C. Jacob, A new Species of Coleus, Journal of Bombay Natural History Society, 42, 1941, 320-322.

[5]. A. Saraswathy, K. Amala and Arunmozhi Devi, Coleus vettiveroides K.C. Jacob; Botany and Pharmacognosy, Indian Journal of Traditional Knowledge, 10(4), 2011, 636-642.

[6]. K. Mengel and E.A. Kirkby, Principles of plant nutrition (International Potash Institute, Worblaufen-Bern/Switzerland, 1978 ) 593.

[7]. M.I. Ezzo, A.A. Glala, A.M. Hoda Habib and A.A. Helaly, Response of Sweet pepper grown in sandy and clay soil lysimeters to water regimes, American-Eurasian J. Agric. \& Environ. Sci., 8(1), 2010, 18-26.

[8]. Jolly Garg and Ashwani Kumar, Effect of different soil types on growth and productivity of Euphorbia lathyris L. a hydrocarbon yielding plant, International Journal of Life Science \& Pharma Research, 2(3), 2012, 164-173.

[9]. R. Singh and R.B. Alderfer, Effect of soil moisture stress at different periods of growth of some vegetable crops, Soil Sci., 101, 1966, 69-80.

[10]. M. Peet, Sustainable practices for vegetable production in south crop profile pepper. (NCSU, USA, 2002).

[11]. K.R. Olson, S.A. Ebelhar and J.M. Lang, Impacts of conservation tillage systems on maize and soybean yields of eroded illinois soils, J. Agron., 3, 2004, 31-35.

[12]. Z. B. Barut and D. Akbolat, Evaluation of conventional and conservation tillage systems for maize, J. Agron., 4, 2005, 122-126.

[13]. Ritu Vishnoi, S. Govind, Rajwar and Prakash C. Kuniyal, Effect of different sand and soil ratios on the growth of Terminalia arjuna W. \& A., New York Science Journal, 3(11), 2010, 22-26.

[14]. R.G.A. Boot and K.C. Den Dubbelden, Effects of nitrogen supply on growth, allocation and gas exchange characteristics of two perennial grasses from Inland Dunes, Oecologia, 85, 1990, 115-121.

[15]. Ryser and H. Lambers, Root and leaf attributes accounting for the performance of fast and slow growing grasses at different nutrient supply, Plant and Soil, 170, 1995, 2512-2565.

[16]. Anjana Devkota and Pramod Kumar Jha, Variation in growth of Centella asiatica along different soil composition, Botany Research International, 2(1), 2009, 55-60.

[17]. T.T. Kozlowski, Soil aeration and growth of forest trees review article, Scandinavian Journal of Forest Research, 1, $1986,113-124$.

[18]. W. Silver, F. Scatena, A. Johnson, T. Siccama and M. Sanchez, Nutrient availability in a montane wet tropical forest - spatial patterns and methodological considerations, Plant and Soil, 164, 1994, 129-145.

[19]. S.P. Sah, S.K. Upadhyay, P. Pandit and J.B. Lilles, Effects of soil on Sissoo (Dalbergia sissoo, Roxb.) growth in a plantation forest of Nepal, Indian Forester, 129 (9-12), 2003, 1059-1068.

[20]. R.L. Parish, R.P. Bracy and J.E. McCoy, Bed height for greens crops, J. Veg. Crop Production, 5(2), 2000, 73-78.

[21]. B. Chipangura and J. Jackson, Sweet potato for high yield in Zimbabwe (Farming World, Harare), $2003,5-12$.

[22]. C. Parwada, C.T. Gadzirayi and A.B. Sithole, Effect of ridge height and planting orientation on Ipomoea batatas (sweet potato) production, Journal of Agricultural Biotechnology and Sustainable Development, 3, 2011, 72-76.

[23]. M.D. Belel, M.S. Saidu and A.A. Sajo, Effect of land preparation and weeding regime on the yield of sweet pepper (Capsicum annuum L.) in Mubi, Adamawa State, Journal of Agronomy, 10, 2011, 62-67.

[24]. G. Alem, Evaluation of tillage practices for soil moisture conservation and maize production in dry land Ethiopia, Agricultural Mechanization in Asia, Africa and Latin America, 24(3), 1993, 9-13. 